\title{
DENSITY EFFECTS AND STAND DENSITY MANAGEMENT DIAGRAM FOR MERKUS PINE IN THE HUMID TROPICS OF JAVA, INDONESIA
}

\author{
Ika Heriansyah $^{1,2,3}$, Sofwan Bustomi ${ }^{4}$, and Yoichi Kanazawa ${ }^{5}$
}

\begin{abstract}
The size and quality of produced timber are greatly affected by the suitability of planting density and the practice of thinning. Density effects on stand growth and development were evaluated in a spacing trial of merkus pine (Pinus merkusii Jungh. et de Vriese), and these data were used to establish a stand density management diagram (SDMD). Growth performance in terms of diameter at breast height $(D)$, total height $(H t)$ and mortality rate were monitored for 32 years when trees were 5-36 years old. Mortality and $D$ growth were positively density related, but $H$ growth was not affected by density. During the measurement period, tree density decreased from 7779 to 679 trees/ha for the closest spacing and from 943 to 514 trees/ha for the widest spacing. Results suggested that optimal harvesting was at about 30 years of age if no thinning occurs. The SDMD was established to predict the course of stand development in merkus pine. The simulation of stand growth under $2 \mathrm{~m} \times 3 \mathrm{~m}$ spacing and thinning options was demonstrated in a SDMD, and suggested reasonable flexibility for practical application. We recommend using this SDMD as a tool to reexamine the thinning regime for enhancing forest productivity and wood utilization.
\end{abstract}

Keywords: Pinus merkusii, spacing trial, stand development, stand density management, diagram, thinning regimes

\section{INTRODUCTION}

Determination of appropriate levels of growing stock at the stand level is a complex process involving biological and technological factors specific to a particular management situation. The process requires selection of upper and lower limits of growing stock, taking into account that the upper limit is chosen to obtain acceptable stand growth and individual tree vigor, and the lower limit is chosen to maintain acceptable site occupancy (Dean and Baldwin, 1996).

\footnotetext{
Forest and Nature Conservation Research and Development Center, Jl. Gunung Batu No. 5, P.O. Box 165, Bogor 16610, Indonesia

2 School of Graduate Studies, Universiti Putra Malaysia, Serdang 43400, Malaysia

3 Corresponding author. E-mail: forestcore@gmail.com

4 Forest Plantation Research and Development Center, Jl. Gunung Batu No. 5, Bogor 16610, Indonesia

5 Graduate School of Agriculture, Kobe University, Kobe 657-8501, Japan
} 
Although field trials are the best way of determining the timing of thinnings, they have two serious limitations (Dean and Baldwin, 1993), they take many years to complete and the results cannot be applied accurately when the site quality and management objectives differ from those encountered in the trials. Density manipulation is one of the most powerful tools available to achieve a broad range of silvicultural objectives. One of the most effective methods of planting density management in even-aged stands is through the use of stand density management diagrams (SDMDs), which are average stand-level models that graphically illustrate the relationships among yield, density, and mortality through all stages of stand development (Newton and Weetman, 1994; Jack and Long, 1996). They allow the user to develop and project crop plans through time, to determine the optimum timing of thinnings, and to contrast potential outcomes from a number of stand management regimes.

The basic theories of stand density and plant growth and the SDMD were developed in Japan in the late 1950s and early 1960s (Kira et al., 1953, 1954, 1956; Shinozaki and Kira, 1956, 1961; Yoda et al., 1963). The use of SDMDs was initially developed by Japanese scientists in the early 1960s (e.g., Ando, 1962, 1968; Tadaki, 1963). During the 1970s and 1980s, various modifications to the original modeling approach, incorporating forest production theories, were proposed (Newton, 1997). Today, these models have been developed for several additional species and mixed stands by employing earlier modeling approaches. These diagrams provide stand-level summaries for making standlevel silvicultural decisions (Hatiya and Fujimori, 1984; Farnden, 2002). Several density indices have been used: the stand density index proposed by Reineke (1933) (e.g., McCarter and Long, 1986; Long et al., 1988; Dean and Jokela, 1992; Dean and Baldwin, 1993; Kumar et al., 1995); the self-thinning rule proposed by Yoda et al. (1963) (e.g., Drew and Flewelling, 1977; Kim et al., 1987); or Drew and Flewelling's (1979) and the relative density index (e.g., Flewelling et al., 1980; Newton and Weetman, 1994; Flewelling and Drew 1985; Farnden, 1996; Newton, 1997, 1998). One great advantage of these density indices is that they are independent of site quality and stand age (Long, 1985; McCarter and Long, 1986).

The objectives of the present study were to evaluate the effects of initial spacing on temporal patterns of growth through a full rotation, and to develop a stand density management diagram for merkus pine (Pinus merkusii Jungh. et de Vries) stands which can be applied for determining thinning regimes. The establishment of SDMD was not expected to explain the growth conditions of the stand, but it is also useful in finding the method of density control best suited to each growth stage of the stands. The tool may be possible to obtain directly an estimate of the forest plantation productivity for any point on the diagrams. This tool will help forest managers to examine optimum thinning 
regimes to attain the scheduled production purpose based on the current status of the plantations.

Merkus pine is one of the most common and commercially important tree species for plantations, occurring across a variety of site types in Indonesia (Hidayat and Hansen, 2002). In Java alone, the area planted by the state-owned enterprise (Perum Perhutani) was 871,000 ha in 2000 (Perum Perhutani, 2001).

\section{MATERIALS AND METHODS}

\section{A. Study Site}

The spacing trial was established in 1969 in the Cikole Forest Reserve, West Java, Indonesia (Figure 1). The site was located at latitude $6^{\circ} 46.541 \mathrm{~S}$ and longitude $107^{\circ} 38.173 \mathrm{E}$, at an elevation of about $1500 \mathrm{~m}$ above sea level. The mean annual rainfall is $2429 \mathrm{~mm}$ and the soil is Andosol, Eutric Hapludands (FORDA, 1991). The trial initially consisted of 25 plots; five spacings of $1 \mathrm{~m} \mathrm{x}$ $1 \mathrm{~m}, 1 \mathrm{~m} \times 2 \mathrm{~m}, 1 \mathrm{~m} \times 3 \mathrm{~m}, 2 \mathrm{~m} \times 3 \mathrm{~m}$ and $3 \mathrm{~m} \times 3 \mathrm{~m}$ and five replications each. Each plot was square, 0.14 ha in area and had two or more exterior isolation rows.

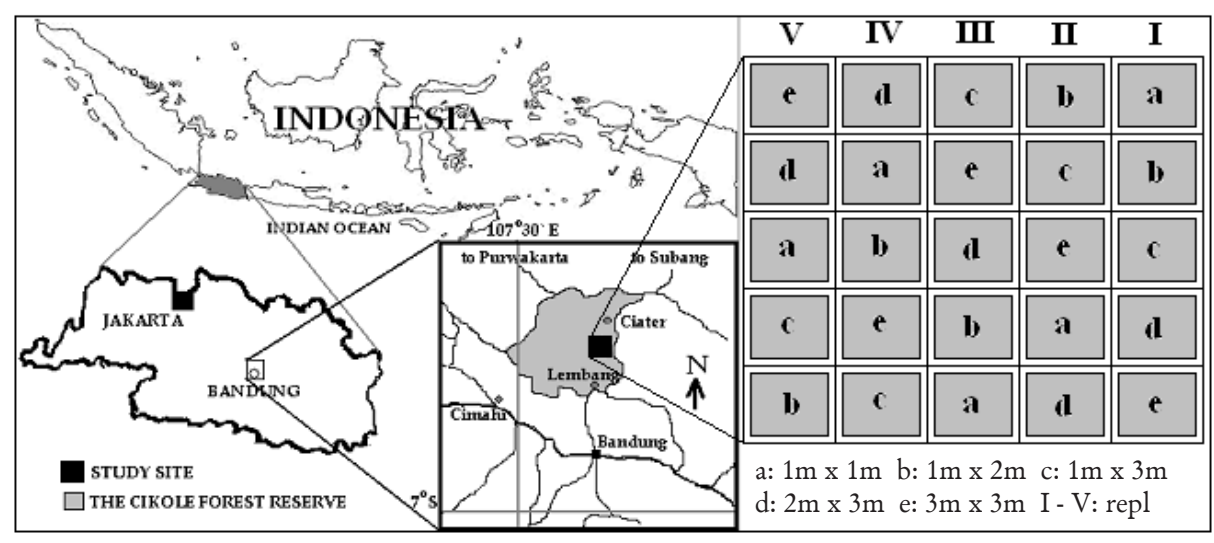

Figure 1. Location of the study site

\section{B. Data Set}

Measurements were made at ages 5, 8, 10,12,15, 23 and 36 years. Diameter at breast height $(D)$, height at the lowest branch $(b)$ and total height $(H t)$ of living sample trees were measured at each measurement time. In summary, a total of 25 plot measurements and their associated total volumes $\left(\mathrm{m}^{3} / \mathrm{ha}\right)$, densities (stems/ha), and average predominant heights $(H ; \mathrm{m})$ were available for 
analysis. Total plot volumes were calculated by combining individual diameter and height measurements with the volume equations proposed by Heriansyah et al. (2006).

\section{Construction of the Stand Density Management Diagram}

The stand density diagram was constructed using the methods of Hatiya and Fujimori (1984). Construction of the stand density diagram involved the following steps:

1. Competition-density (C-D) and yield-density (Y-D) effect analysis

The mean stem volume and stand density are related by the competitiondensity (C-D) effect. Because conditions for growth were identical through time, and growth of all trees started at the same time, the only variable was stand density. Then, the relationship after a certain period of time was defined as:

$1 / g=A \rho+B$,

where $g$ is the mean stem volume $\left(\mathrm{m}^{3}\right), \rho$ is the stand density (trees ha $\mathrm{a}^{-1}$ ), and $A$ and $B$ are constants and a function of time. Equation 1 is called the reciprocal C-D equation (Shinozaki and Kira, 1956, 1961). 
Stand volume is obtained by multiplying $g$ and $\rho(G=g \times \rho)$, and substitution of this equation into Equation 1 results in

$1 / G=A+B / \rho$

This relationship is the Y-D effect, and Eq. 2 is called the reciprocal Y-D equation (Shinozaki and Kira, 1956, 1961). Yield as used here is equivalent to production.

2. Predominant height determination

The relationship between the growth of forest trees and stand density is expressed ideally by the reciprocal equations for each stand age, meaning the constants $A$ and $B$ in the equations are determined for each growth stage of the forest. Furthermore, assuming that the average predominant height $(H$; an average height of the 25 tallest trees of each spacing) of the stand expresses the growth stage or site condition of the stand, and that stands having similar $H$ are at the same growth stage as each other, the various equivalent $H$ curves can be expressed with the reciprocal equation. Thus, the variation in $A$ and $B$ in the reciprocal equation is approximated by the following equations:

$\log A=a \log H+b$

$\log B=a^{\prime} \log H+b^{`}$

where $A$ and $B$ are constants to be determined by $H$, and $a, b, a^{\prime}$, and $b^{\prime}$ are constants.

3. Equivalent height curve and equivalent diameter curve determination

Equations (1), (3), and (4) were used to derive an equivalent height curve that was determined by the relationship between the constants of the reciprocal equations and $H$ for all stand ages. After constants $a, b, a^{\prime}$, and $b^{\prime}$ were determined, values $A$ and $B$ of every height grade were to be determined, given at intervals of $2 \mathrm{~m}$. The equivalent height curve, therefore, was determined by using Eq. (1). Equivalent diameter curves were obtained by plotting the diameters and densities calculated from the equation showing the relationship between basal area and density for a specific height grade, given at intervals of $2 \mathrm{~cm}$ in terms of diameter grade.

4. Yield index curve and self-thinning curve analysis

Each species has an upper limit of density in each stage of growth, and densities exceeding this limit are seldom seen. In an overstocked stand where 
natural thinning is an important force, $\rho, g$, and $G$ are tied together in the following relationship:

$g=k \rho^{-a}$

$G=k \rho^{1 \cdot a}$,

where $k$ and $a$ are constants inherent in species.

\section{RESULTS AND DISCUSSION}

\section{A. Results}

1. Density effect on survival rate, height, and diameter growth

Summary statistics for the data set and the age trend in survival, tree height and diameter by spacing are shown in Table 1 and Figure 2, respectively. Mortality in the Cikole Forest Reserve was density-related; no causes other than competition for growing space were identified, except for minor mortality after planting. Self-thinning began earliest and trees died in the greatest numbers in the $1 \mathrm{~m} \times 1 \mathrm{~m}$ and $1 \mathrm{~m} \times 2 \mathrm{~m}$ spacing. By age 8 , about 50.9 and $43.4 \%$ of the trees in the $1 \mathrm{~m} \times 1 \mathrm{~m}$ and $1 \mathrm{~m} \times 2 \mathrm{~m}$ plots had died, respectively, and although mortality had begun to occur in the $1 \mathrm{~m} \times 3 \mathrm{~m}$ and $2 \mathrm{~m} \times 3 \mathrm{~m}$ plots, only 38.7 and $37.4 \%$ had died by the fifth year, respectively. About $25.4 \%$ of the trees in the $3 \mathrm{~m} \times 3 \mathrm{~m}$ plots had died by the fifth year (Table 1, Figure 2). The survival curve declined progressively up to age 15 years in the most densely planted plots of $1 \mathrm{~m} \times 1 \mathrm{~m}$, up to age 10 years in the $1 \mathrm{~m} \times 2 \mathrm{~m}$ and $1 \mathrm{~m} \times 3 \mathrm{~m}$ spacings, and up to age 5 years in the two widest spacings, with all declines converging as a result of self-thinning. At age 23, the curves of the closest and widest spacings were 3450 and 793 trees/ha, respectively. When mature stands were still at high densities, high competition occurred and mortality increased progressively at the closest spacing, followed by wider spacings. At the last measurement at age 36, stand density had become $697,750,757,543$, and 514 trees/ha for the $1 \mathrm{~m} \times 1 \mathrm{~m}, 1 \mathrm{~m}$ x $2 \mathrm{~m}, 1 \mathrm{~m} \times 3 \mathrm{~m}, 2 \mathrm{~m} \times 3 \mathrm{~m}$, and $3 \mathrm{~m} \times 3 \mathrm{~m}$ spacings, respectively.

Spacing had no significant effect on average stand height, although trees in the $3 \mathrm{~m} \times 3 \mathrm{~m}$ spacing were consistently taller than those in the closer spacings as early as the fifth year (Table1, Figure 2). However, differences in mean $D$ among spacings were apparent 5 years after planting. During the 18 years between ages 5 and 23 , the $3 \mathrm{~m} \times 3 \mathrm{~m}$ spacing trees had a mean $D$ of $20.9 \mathrm{~cm}, 68.5 \%$ greater than the trees spaced at $1 \mathrm{~m} \times 1 \mathrm{~m}$, which grew to $12.4 \mathrm{~cm}$. This indicates that competition in closer spacing is more intense than in wider spacing. 
Density Effects and ..... I. Heriansyah et al.

Table 1. Means for stand components of the Cikole Forest Reserve, West Java, at age of measurement

\begin{tabular}{|c|c|c|c|c|c|c|c|}
\hline \multirow{2}{*}{ Spacing $^{\mathrm{a}}(\mathrm{m})$} & \multicolumn{7}{|c|}{ Stand age (years) } \\
\hline & 5 & 8 & 10 & 12 & 15 & 23 & 36 \\
\hline \multicolumn{8}{|l|}{ Surviving (trees/ha) } \\
\hline $1 \mathrm{~m} \times 1 \mathrm{~m}$ & 7779 & 4907 & 4200 & 3964 & 3464 & 3450 & 679 \\
\hline $1 \mathrm{~m} \times 2 \mathrm{~m}$ & 3986 & 2829 & 2036 & 1921 & 1707 & 1664 & 750 \\
\hline $1 \mathrm{~m} \times 3 \mathrm{~m}$ & 2436 & 2043 & 1700 & 1579 & nd & 1414 & 757 \\
\hline $2 \mathrm{~m} \times 3 \mathrm{~m}$ & 1121 & 1043 & 957 & 929 & 929 & 900 & 543 \\
\hline $3 \mathrm{~m} \times 3 \mathrm{~m}$ & 943 & 829 & 793 & 793 & 793 & 793 & 514 \\
\hline \multicolumn{8}{|l|}{ Mean height (m) } \\
\hline $1 \mathrm{~m} \times 1 \mathrm{~m}$ & 4.5 & 7.3 & 11.6 & 13.4 & 15.4 & 21.3 & 32.3 \\
\hline $1 \mathrm{~m} \times 2 \mathrm{~m}$ & 5.3 & 9.8 & 12.3 & 14.4 & 16.4 & 21.6 & 29.6 \\
\hline $1 \mathrm{~m} \times 3 \mathrm{~m}$ & 5.8 & 9.5 & 12.5 & 14.4 & nd & 22.2 & 34.7 \\
\hline $2 \mathrm{~m} \times 3 \mathrm{~m}$ & 5.6 & 7.3 & 12.5 & 14.3 & 16.6 & 22.6 & 33.2 \\
\hline $3 \mathrm{~m} \times 3 \mathrm{~m}$ & 6.3 & 8.1 & 12.1 & 13.8 & 16.4 & 22.2 & 32.6 \\
\hline Predominant height (m) & 8.3 & 11.3 & 15.2 & 17.3 & 19.3 & 25.4 & 38.1 \\
\hline \multicolumn{8}{|l|}{ Mean diameter $(\mathrm{cm})$} \\
\hline $1 \mathrm{~m} \times 1 \mathrm{~m}$ & 5.2 & 9.4 & 11.5 & 12.9 & 14.7 & 17.6 & 34.3 \\
\hline $1 \mathrm{~m} \times 2 \mathrm{~m}$ & 6.7 & 11.1 & 14.2 & 16.4 & 19.1 & 22.7 & 31.7 \\
\hline $1 \mathrm{~m} \times 3 \mathrm{~m}$ & 8.0 & 13.1 & 16.1 & 18.3 & nd & 24.7 & 32.6 \\
\hline $2 \mathrm{~m} \times 3 \mathrm{~m}$ & 8.3 & 14.5 & 18.4 & 21.1 & 23.1 & 27.9 & 38.2 \\
\hline $3 \mathrm{~m} \times 3 \mathrm{~m}$ & 9.1 & 16.2 & 20.0 & 23.3 & 25.4 & 30.0 & 41.4 \\
\hline \multicolumn{8}{|l|}{ Stand volume $\left(\mathrm{m}^{3} / \mathrm{ha}\right)$} \\
\hline $1 \mathrm{~m} \times 1 \mathrm{~m}$ & 59.82 & 169.68 & 328.68 & 449.42 & 569.42 & 1044.00 & 1066.51 \\
\hline $1 \mathrm{~m} \times 2 \mathrm{~m}$ & 58.23 & 174.21 & 240.89 & 349.47 & 467.31 & 822.88 & 950.85 \\
\hline $1 \mathrm{~m} \times 3 \mathrm{~m}$ & 50.00 & 163.35 & 260.19 & 353.10 & nd & 826.69 & 1137.16 \\
\hline $2 \mathrm{~m} \times 3 \mathrm{~m}$ & 23.02 & 81.74 & 182.60 & 265.51 & 363.56 & 664.96 & 1087.59 \\
\hline $3 \mathrm{~m} \times 3 \mathrm{~m}$ & 24.21 & 80.61 & 167.60 & 253.09 & 353.03 & 634.50 & 1089.39 \\
\hline
\end{tabular}

Note: $\quad$ Trees planted per ha: $1 \mathrm{~m} \times 1 \mathrm{~m}=10000 ; 1 \mathrm{~m} \times 2 \mathrm{~m}=5000 ; 1 \mathrm{~m} \mathrm{x} 3 \mathrm{~m}=3333 ; 2 \mathrm{~m} \mathrm{x}$ $3 \mathrm{~m}=1667$ and $3 \mathrm{~m} \times 3 \mathrm{~m}=1111$. nd: no data. Predominant height was determined as an average height of the 25 tallest trees for each spacing. 

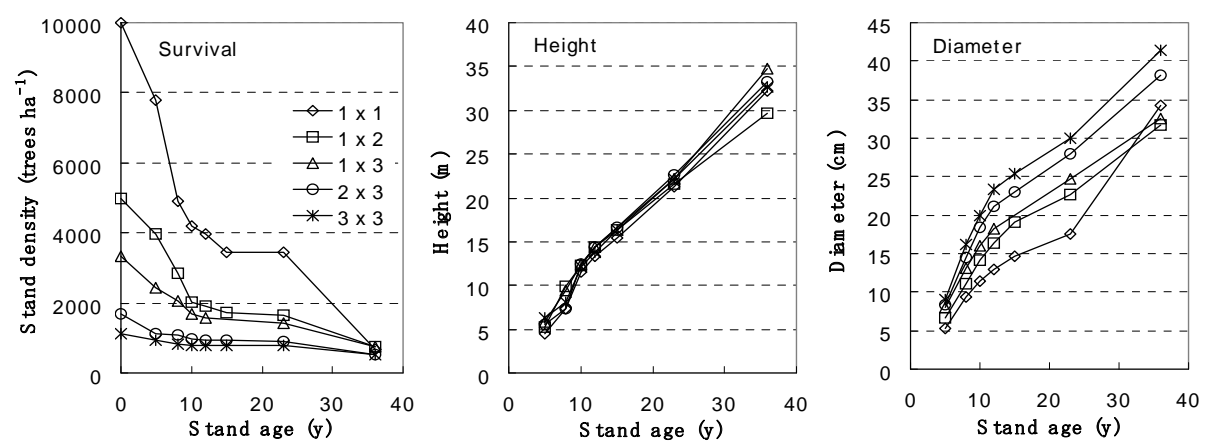

Figure 2. Age trends in survival, tree height and diameter by spacing

Stand differentiation resulting from differential growth among the component trees (Oliver and Larson, 1990) was examined by evaluating $D$ size-class frequency distribution in 5 -cm class widths. The time trend of the frequency distribution of $D$ in each stand is given in Figure 3. In early growth at 5 years of age, the dominant $D$ class was between 0 and $10 \mathrm{~cm}$ for the closest spacing and between 5 and $10 \mathrm{~cm}$ for wider spacings.

The dead trees belonged to the lowest class, indicating that smaller trees died as the stand grew. At age 23 , the dominant $D$ class for the $1 \mathrm{~m} \times 1 \mathrm{~m}$ spacing was between 10 and $20 \mathrm{~cm}(70.3 \%)$, while $72.2 \%$ of the $D$ class ranged from 25 to $35 \mathrm{~cm}$ in the $3 \mathrm{~m} \times 3 \mathrm{~m}$ spacing. At age 36 , the $1 \mathrm{~m} \times 1 \mathrm{~m}$ spacing was dominated by trees with $D$ between 30 and $40 \mathrm{~cm}(55.8 \%)$, while $73.6 \%$ of trees had a $D$ larger than $35 \mathrm{~cm}$ in the $3 \mathrm{~m} \times 3 \mathrm{~m}$ spacing. 


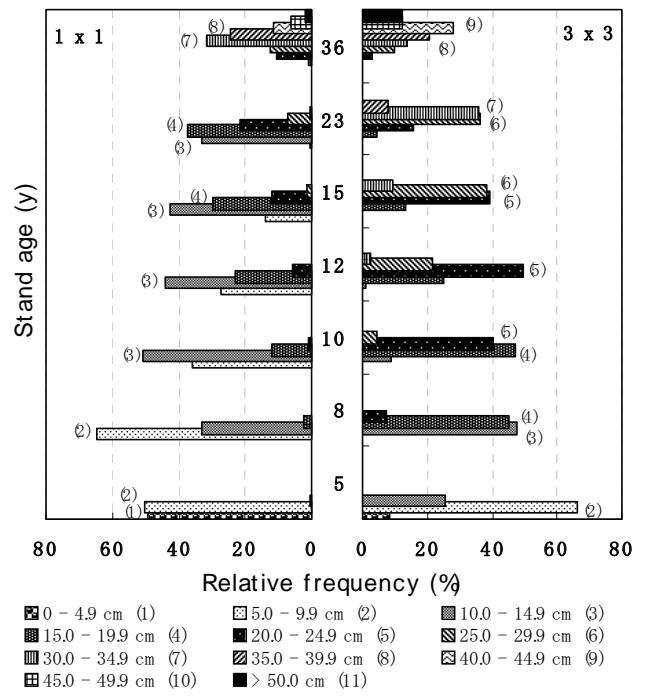

Figure 3. Transition of the frequency distribution of $\mathrm{D}$ in $1 \mathrm{~m} \times 1 \mathrm{~m}$ and $3 \mathrm{~m} \times 3 \mathrm{~m}$ spacing. Relative frequencies are shown in 11 equal intervals in the range of $\mathrm{D}$.

Observations for all stand ages revealed that mortality during self-thinning tends not to be random, but is concentrated among the smaller individuals in the stand. Thus, the reduction in density that occurs during self-thinning is accompanied by a change in the size structure of the population (Jones and Harper, 1987).

2. Stand density management diagram

Competition-density $(C-D)$ and yield-density $(Y-D)$ effect

The C-D and Y-D effects on stem volume for Merkus pine is shown in Figure 4. Figure 4 a shows the reciprocal C-D relationship of Eq. (1), and shows that at low stand densities, individual stem volume increase with time independently of stand density in early stages, and when the stand density exceeds a certain level, the growth of individuals is constrained by competition. This is an indication that competition under closer spacing conditions is more intense than under wider spacing. Figure $4 \mathrm{~b}$ shows the relationship between yield and density, which is almost symmetrical to Figure 4a. At low densities, yield increases in proportion to density, but at high densities yield is limited, until at the highest density, the yield approaches a constant level. The relationship between stand density and the growth of forest trees on stem volume is summarized in Table 2. 
Journal of Forestry Research Vol. 5 No. 2, 2008:91-113

Table 2. C-D effect on mean stem volume of merkus pine

\begin{tabular}{cccrc}
\hline Parameter & Stand age & A & \multicolumn{1}{c}{ B } & \multicolumn{1}{c}{$\mathrm{r}^{2}$} \\
\hline & 5 & 0.0128 & 25.2320 & 0.9570 \\
& 8 & 0.0043 & 6.2017 & 0.9100 \\
1/mean stem volume & 10 & 0.0024 & 2.9619 & 0.9839 \\
& 12 & 0.0018 & 1.8066 & 0.9950 \\
& 15 & 0.0014 & 1.1933 & 0.9990 \\
& 23 & 0.0008 & 0.6598 & 0.9969 \\
\hline
\end{tabular}

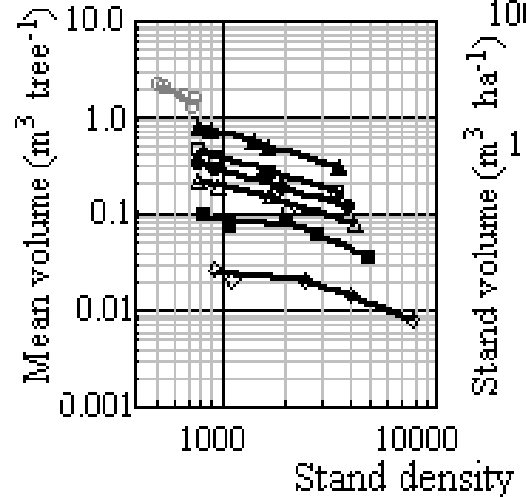

(a)

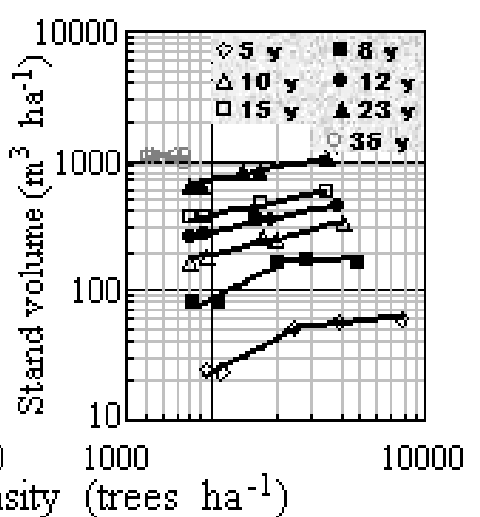

(b)

Figure 4. The effects of stand density on stem volume in Merkus pine.

Equivalent height curve, equivalent diameter curve and the yield index curve

Equation relationship between $H$ and constants $A$ and $B$ in the reciprocal equation that uses for the equivalent height curve determination are shown in Figure 5. Furthermore, various $H$ lines and $D$ lines plotted on density and the stem volume graphs are shown in Figure 6. 


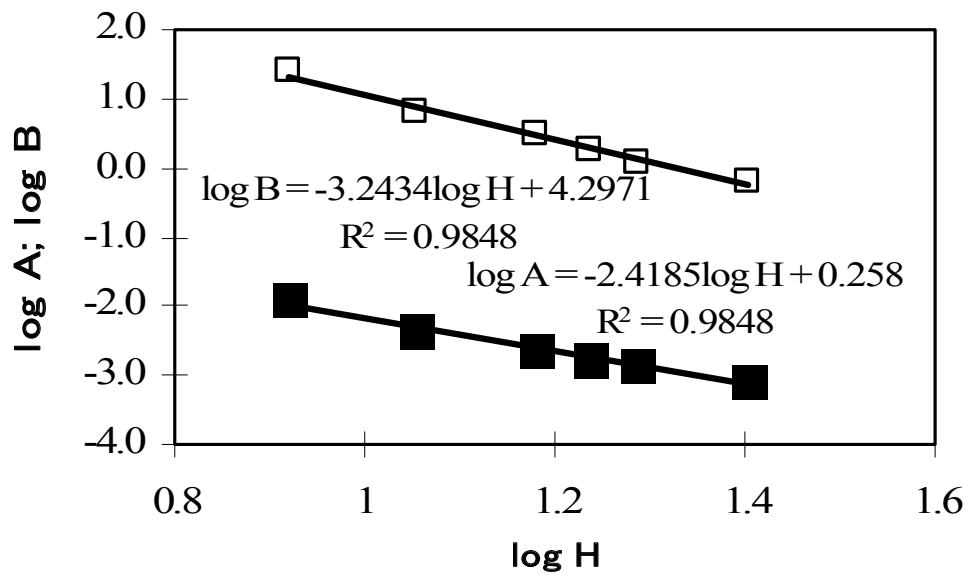

Figure 5. Relationship between $\mathrm{H}$ and constant $\mathrm{A}$ and $\mathrm{B}$ in the reciprocal equation used as the equivalent height curve of stem volume.

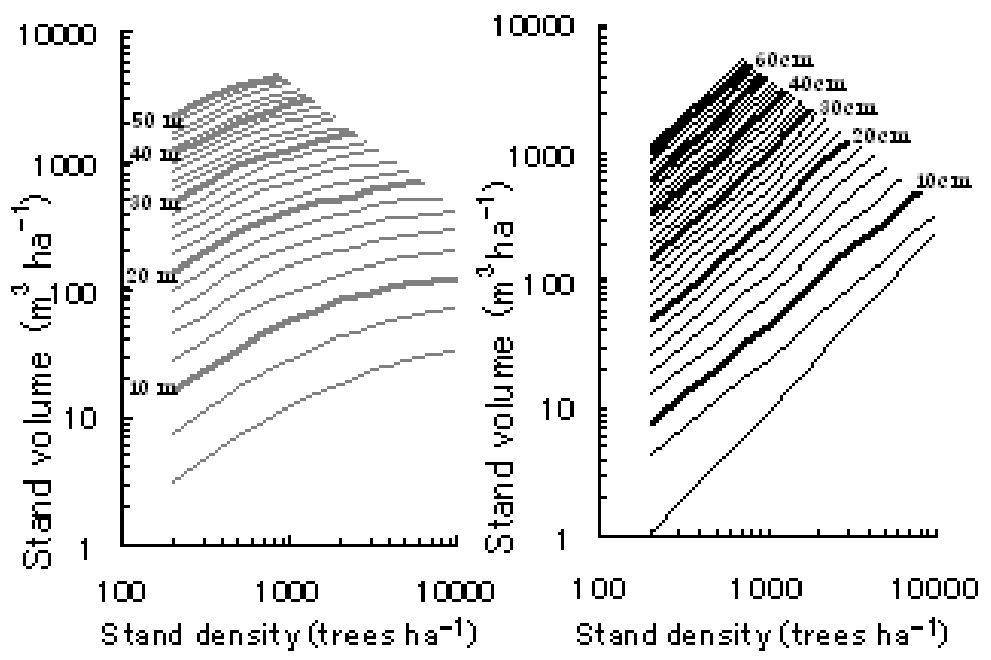

Figure 6. Density effects on the stem volume for (a) various mean heights of predominant trees and for (b) various mean diameters. 
In equation 5 , the coefficient $k$ changes depending on species, and the coefficient $a$ is usually around $3 / 2$ (Kira, 1957; Shinozaki, 1959). The coefficient $k^{\prime}(=\log$ $k$ ) and the coefficient $a$ for stem volume in this study are 5.47987 and 1.8459, respectively. Equations (5) and (6) are not related to the growth stage and site conditions. They express the upper limits of density characteristics for each species. The curves given by these equations are called the full density curves, and are followed by curves running parallel, called yield index curves $(R y)$. The $R y$ denotes the ratio of the stand volume at a specific density to the stand volume area at full density for a specific height grade (Hatiya and Fujimori, 1984).

This study provided stand density management diagram based on stem volume as shown in Figure 7. Figure 7 is a graphical representation of the density effect on the stand volume of Merkus pine for various mean heights of predominant trees and various mean diameters. The diagram contains all these elements on a single sheet, such as stand density, equivalent height curves (gray lines), equivalent diameter curves (parallel black lines), full density curve and yield index curves in the lower section, the actual natural thinning curves, and stand volume. By using this diagram, we can predict the growth of the forest at any given future point.

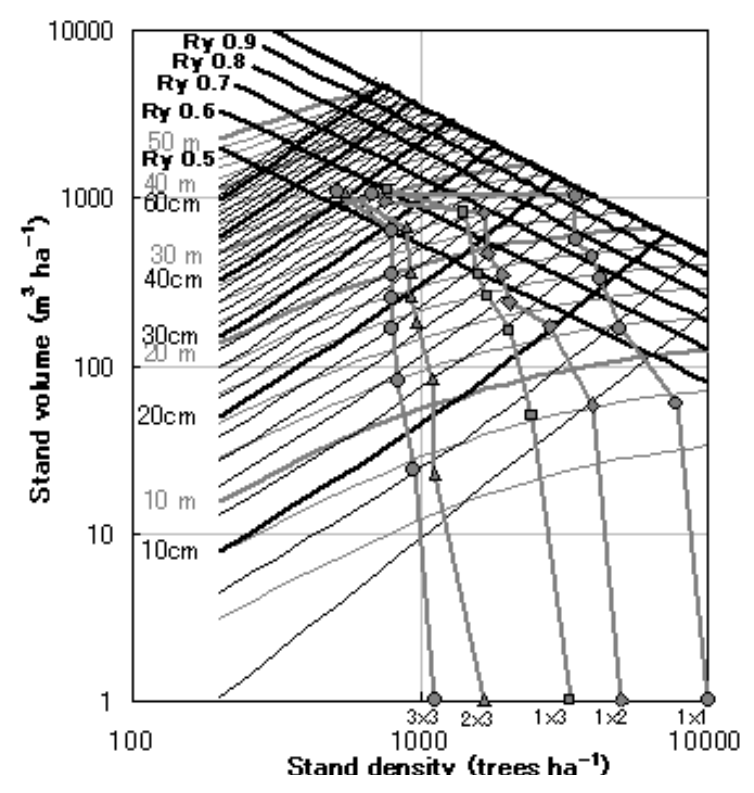

Figure 7. The stand density management diagram for Merkus pine in Cikole Forest Reserve, based on stem volume. The curves standing almost perpendicular to the abscissa and turning to the left represent the actual self-thinning curves from different initial spacings. 


\section{Development of a silvicultural schedule and yield determination}

Two factors determine the schedule of thinning within the framework of the density management diagram: the target dominant height and/or diameter at rotation age and the lower and upper growing stock limits. Although these criteria are usually determined by timber objectives, they can also be set according to any non-timber objective that can be expressed in terms of tree size and trees per hectare (Dean and Baldwin, 1993).

Selection of lower and upper growing stock limits often represents a silvicultural trade-off between maximum stand growth and maximum individual tree growth and vigor (Long, 1985). Thus, the decision regarding appropriate levels of growing stock will reflect stand management objectives.

The principal objective in setting the lower growing stock limit is to maintain adequate site occupancy. The lower limit is usually set using a constant value of relative spacing index somewhat above canopy closure because it marks the beginning of competition for resources.

The development of a stand under two different thinning regimes is illustrated in Figure 8. The sequence of thinnings required to reach these points are found by stair-stepping backwards, taking into account the upper growing stock limit and the thinning interval.

\section{Simulation for stand volume development}

The simulation for stand development was made under two types of silvicultural option; the combination of one kind of spacing $(2 \mathrm{~m} \times 3 \mathrm{~m})$ and a choice of thinning treatment, i.e., course 1 and course 2 . The course 2 is provided if the first thinning performs later and for getting some early income of harvested trees. In this simulation, thinning is supposed to be performed two times: at ages 8 and 15 years with 23.3 and $50 \%$ culling rate (course 1 ) or at ages 10 and 15 years with 16.4 and 50\% culling rate (course 2) respectively, during the 36-year rotation assuming that thinning does not change mean predominant height. The first thinning called pre-commercial thinning with the best 800 trees $\mathrm{ha}^{-1}$ of remained trees, and the second/last thinning called commercial thinning with the best $\mathbf{4 0 0}$ trees/ha of remained trees. 
Journal of Forestry Research Vol. 5 No. 2, 2008: 91-113

Table 3. Value changes in stand volume by thinning course

\begin{tabular}{|c|c|c|c|c|c|}
\hline Stand age & $H(\mathrm{~m})$ & $\begin{array}{c}\text { Thinning } \\
(\%)\end{array}$ & $\begin{array}{c}\text { Stand density } \\
\left(\text { trees } \mathrm{ha}^{-1}\right)\end{array}$ & $\begin{array}{l}\text { Volume } \\
\left(\mathrm{m}^{3} \mathrm{ha}^{-1}\right)\end{array}$ & $\begin{array}{l}\text { Harvest } \\
\left(\mathrm{m}^{3} \mathrm{ha}^{-1}\right)\end{array}$ \\
\hline \multicolumn{6}{|l|}{ Self-thinning } \\
\hline 8 & 11.3 & 0 & 1043 & 81.74 & \\
\hline 10 & 15.2 & 0 & 957 & 182.60 & \\
\hline 15 & 19.3 & 0 & 929 & 363.56 & \\
\hline \multirow[t]{2}{*}{36} & 38.1 & 0 & 543 & 1087.59 & 1087.59 \\
\hline & & & & Total & 1087.59 \\
\hline \multicolumn{6}{|l|}{ Course 1} \\
\hline \multirow[t]{2}{*}{8} & 11.3 & & 1043 & 81.74 & \\
\hline & & 23.3 & 800 & 67.99 & 13.75 \\
\hline \multirow[t]{2}{*}{15} & 19.3 & & 800 & 317.92 & \\
\hline & & 50 & 400 & 205.45 & 112.47 \\
\hline \multirow[t]{2}{*}{36} & 38.1 & & 400 & 1505.16 & 1505.16 \\
\hline & & & & Total & 1631.38 \\
\hline \multicolumn{6}{|l|}{ Course 2} \\
\hline \multirow[t]{2}{*}{10} & 15.2 & & 957 & 182.60 & \\
\hline & & 16.4 & 800 & 160.47 & 22.13 \\
\hline \multirow[t]{2}{*}{15} & 19.3 & & 800 & 317.92 & \\
\hline & & 50 & 400 & 205.45 & 112.47 \\
\hline \multirow[t]{2}{*}{36} & 38.1 & & 400 & 1505.16 & 1505.16 \\
\hline & & & & Total & 1639.76 \\
\hline
\end{tabular}




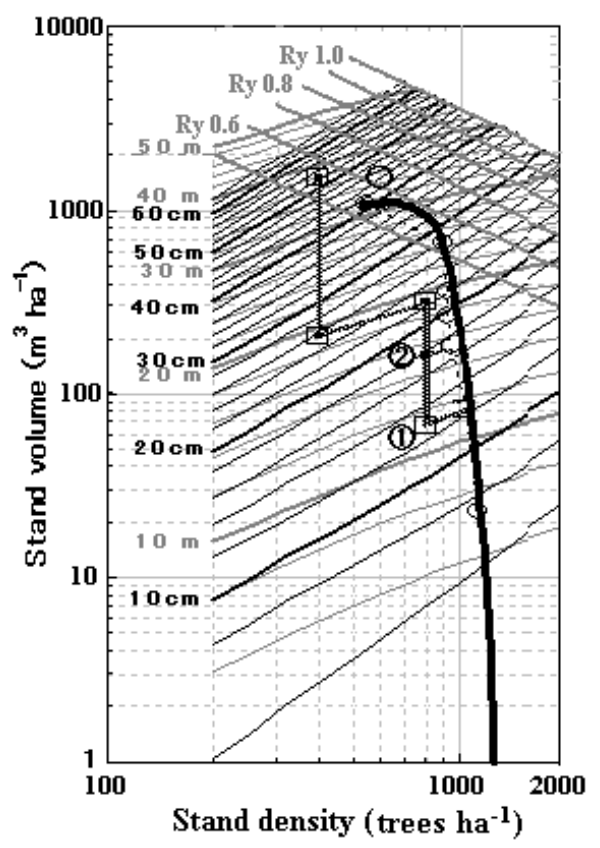

Figure 8. Course of stand volume development predicted by SDMD under the $2 \mathrm{~m} \times 3 \mathrm{~m}$ spacing and thinning option. $\odot$ : natural thinning; $\square$ : course 1 (first thinning at 8 years old); $\square$ : course 2 (first thinning at 10 years old)

The predicted course of stand volume development is shown in Figure 8 and Table 3. Initial density is 1667 trees/ha, with thinning starting at 8 years of age at $11.3 \mathrm{~m}$ predominant height. In that time, density should have been reduced to about 1043 trees/ha as a result of natural thinning (actual data; Table 1), and stand volume will be about $81.74 \mathrm{~m}^{3} / \mathrm{h}$. If the trees are thinned by about 23.3 $\%$ here, then the remaining density will be about 800 trees/ha. The difference in stand volume before and after thinning is about $13.75 \mathrm{~m}^{3}$ for 243 trees felled.

When the tree height is $19.3 \mathrm{~m}$ (15 years), the second thinning is to be carried out. The second thinning will remove $50 \%$, or about 400 trees, leaving 400 trees standing. Stand volume before thinning is $317.92 \mathrm{~m}^{3}$ and after thinning is about $205.45 \mathrm{~m}^{3}$; thus, about $112.47 \mathrm{~m}^{3}$ of volume is thinned. If thinning is performed following this method, productivity until the year of 36 will increase by $543.79 \mathrm{~m}^{3}$ from 1087.59 to $1631.38 \mathrm{~m}^{3}$ for course 1 and by 552.17 $\mathrm{m}^{3}$ for course 2 (Table 3). With thinning, the predicted diameters at the 36year rotation age exceed $52.0 \mathrm{~cm}$, while they are equal to $40.0 \mathrm{~cm}$ when the plantations are left un-thinned (Figure 8). 


\section{B. DISCUSSION}

\section{Density effects on stand development}

Stand development is the process of structural change that occurs in stands over time. Stand development begins at the earliest point of stand establishment and influences the pattern of tree growth, stand structure and timber production throughout its life. The concept of growing space is helpful in explaining the stand development process. The relative importance of growing space varies with species, site, and tree and stand developmental stage. A tree must continue to grow in size and acquire more space if it is to continue to thrive. Trees without adequate growing space grow poorly; those that fail to meet their minimum requirements for growth will die.

In even-aged merkus pine stands, trees are unrestrained by space from establishment until they begin to compete for the site resources, until the age of 5 and 8 years for the three closest spacing and for the widest spacing, respectively. This phase of tree growth is referred to as the period of free growth. Stand volume production is proportional to the number of trees occupying the site during this period. This period ends when the branches of adjacent trees meet and interlock in an attempt to use the same resources. The upper point of inter-tree crown contact moves upward and shading of the lower branches intensifies as crown expansion continues. The lowermost branches eventually die and the bases of the crowns of adjacent trees begin to lift at the same rate.

When inter-tree crown contact occurs, the branches of the more vigorous trees gradually overstep the lateral edge of the crowns of weaker trees. At this point the survival of these trees of lower vigor is threatened because they cannot increase in height fast enough to stay ahead of the receding base of their crowns. Their crowns gradually decline in size to the point where they are unable to maintain their rate of height growth.

Individual tree variation in growth promotes the differentiation of trees into stratified crown classes. Differentiation is expressed as differences in total height, crown size and stem diameter throughout the life of the stand. The process of differentiation is accentuated by tree-to-tree variations in vigor, microsite quality and the time of establishment relative to other trees. The rate of differentiation later accelerates with inter-specific competition.

Mortality occurs when competition for growing space reduces the size and productive capacity of the crown to the point where it cannot support the basic respiration needs of the tree (respiration $>$ photosynthesis). That is, the site-limited resources are redirected from the overtopped and dying trees to the survivors. The onset of regular mortality signals full site occupation or utilization. Competition and the associated tree mortality in dense stands can 
leave a more productive stand at maturity than one established at a much lower density, if only the most vigorous trees survive.

Plantation spacing in the Cikole Forest Reserve, West Java, Indonesia ranged from $1 \mathrm{~m}$ (10,000 trees per ha) to $3 \mathrm{~m}$ (1,111 trees per ha). Tree-totree spacing in natural stands covers a much wider range and is much less regular. Full site occupancy is achieved quickly when the establishment density is moderately high and the spatial distribution of trees is uniform. Uniformity increases in importance as establishment density decreases. Site occupation by tree crowns and merchantable volume decline in response to decreasing establishment density. Any clumping of the same number of stems will reduce the stand yield even further. Low-density stands produce less volume initially because there are too few trees to exploit the available growing space. The rate of stand growth improves after crown closure.

\section{Stand density management diagram}

Stand density management practices include the spacing arrangement of planted trees, pre-commercial thinning (juvenile spacing) and commercial thinning. These practices can have a significant impact on the structure, health and pattern of stand development, which in turn influences stand composition and utility through time. Appropriate decisions may enhance future stand values, tree and wood properties, and habitat characteristics. Inappropriate decisions will at best fail to achieve management objectives, and may compromise future stand values, stand health, or both.

This study provides essential information on tree growth elements, and provides a simulation for making site-specific density management prescriptions. They provide information useful in all aspects of stand density management planning, and all practices including initial spacing, and pre-commercial and commercial thinning.

The growth and yield of trees and stands are fundamental to an understanding of the relationships between density management and timber production. Stand density changes from establishment to maturity in response to natural processes and management interventions such as plantation spacing, pre-commercial thinning and commercial thinning. These and all other silviculture treatments which affect tree spacing will influence the subsequent growth of the stand and the harvest yield.

Density management techniques such as spacing arrangement and thinning manipulate the growing space and resources available to each tree. These silviculture treatments control crown and root development, the size and quality of each tree and the productivity of the stand. 
A specific target stand density can be achieved at an early age by means of initial spacing or pre-commercial thinning. This study proposed initial spacing of $2 \mathrm{~m} \times 3 \mathrm{~m}$ and pre-commercial thinning at the age of 8 or 10 years. The silvicultural benefits for both practices, in terms of average diameter growth, are due to the extended period of free growth before crown closure. High regeneration density followed by pre-commercial thinning provides unique silvicultural advantages over spacing because of the opportunity to select the best trees.

Pre-commercial thinning immediately reduces the number of trees, the occupancy of growing space and the standing volume per hectare. The magnitude of the reduction is related to the intensity of treatment. The response of precommercial thinning is also affected by the product objectives and the stage at which the impact of treatment is assessed. An un-thinned stand can produce more or less wood depending on the merchantability standard applied and when it is evaluated. A lower diameter limit accounts for the many small trees in the untreated stand once they reach pole stage and attains greater volume per hectare than a spaced stand. However, thinning provides more growing space for the left trees, permitting greater diameter growth, allowing trees to cross diameter thresholds more quickly. Notice that the volume benefits of pre-commercial thinning diminish as an increasing proportion of the trees in the un-thinned stand exceed the minimum diameter. Consequently, treatment response should not be assessed at an early age using a relatively large diameter limit.

A commercial thinning entry is designed to capture imminent mortality due to competition, and to modify the stand so that continued stand development will enhance the quality or growth of the remaining trees. The commercial thinning for merkus pine is proposed to be performed at the age of 15 years when the growth of the stand starts to slow down due to competition, and when the volume of the excess stems to be removed is sufficient to make the operation profitable.

The purposes of the control diagram are not limited to explaining the growth conditions of a stand; it is also useful in finding the method of density control best suited to each growth stage of the stand. According to the result of the simulations, thinning was found to be essential to enhance diameter growth with this spacing arrangement. As demonstrated in Figure 8, the procedure proposed here could be utilized as a tool to examine optimum tending regimes for Merkus pine because the procedure can predict both the diameter growth and stand density under different levels of initial spacing as if the results were from an actual spacing trial. 
A yield index representing site productivity was incorporated into the variables to predict stem volume growth (Figure 5). Therefore, the procedure can be regarded as a tool for predicting stand growth linked with the theory of the competition-density and yield-density relationships. This tool would thus help forest managers to examine optimum thinning regimes to attain the scheduled production purpose based on the current status of the plantation. If data from permanent sample plots with two or more measurements are available, a mortality equation can also be constructed and included in the diagram.

Total yield can be obtained directly for any point on the diagram using the stand volume isolines. The sum of volumes removed during each thinning (the difference between volume before and after thinning) and volume at the end of the rotation represent an estimate of the total volume produced by a specific density management regime. Finally, it is possible to obtain directly an estimate of the total volume for any point on the diagram.

\section{CONCLUSIONS}

The responses of merkus pine trees in West Java to initial spacing have been investigated, and the patterns of tree and stand responses to initial spacing of merkus pine were found to be consistent with spacing effects.

It was evident from the data that the critical factors accounting for differences in yield between spacings were tree survival and diameter growth. Tree height was not a factor responsible for growth differences because spacing did not have a significant effect on height growth.

Stand density management decisions affected various links in the value recovery chain, including both tree and wood quality, harvesting and milling costs, product value and financial return. The optimal combination of stocking density and harvest age for each species varied widely with end products produced.

An SDMD for predicting stand development courses was proposed for merkus pine in the humid tropics of Java, Indonesia, and the predicted values of development were reasonably accurate in describing stand development within the range of stand densities examined. Therefore, the thinning regime proposed in this study could be used to reexamine the tending regime that would be most suitable for enhancing forest productivity and wood utilization of merkus pine plantations. 


\section{ACKNOWLEDGEMENT}

We thank the many technicians of the Forest and Nature Conservation Research and Development Center for their assistance in maintaining the experiment and conducting measurements; the technical staff of the Perum Perhutani for their assistance in the field; and Jeanine Pfeiffer for her critique on the findings of this study.

\section{REFERENCES}

Ando, T. 1962. Growth analysis on the natural stands of Japanese red pine (Pinus densiflora Sieb. et. Zucc.). II. Analysis of stand density and growth. Bulletin No. 147. Government Forest Experiment Station, Tokyo [In Japanese with English summary]

Ando, T. 1968. Ecological studies on the stand density control in even-aged pure stands. Bulletin No. 210. Government Forest Experiment Station, Tokyo [In Japanese with English summary]

Davis, K.P. 1966. Forest Management: Regulation and Valuation, 2nd Edn. McGraw-Hill, New York

Dean, J. and J. Jokela. 1992. A density-management diagram for slash pine plantations in the lower coastal plain. Southern Journal of Applied Forestry 16: 178-185.

Dean, T.J. and V.C. Baldwin. 1993. Using a density-management diagram to develop thinning schedules for loblolly pine plantations. Research Paper SO 275. USDA Forest Service. Southern Forest Experimental Station, Atlanta, GA.

Dean, T.J. and V.C. Baldwin. 1996. Crown management and stand density. In: M.C. Carter (Ed.) Growing Trees in a Greener World: Industrial Forestry in the $21^{\text {st }}$ Century; $35^{\text {th }}$ LSU Forestry Symposium. Louisiana State University Agricultural Center, Louisiana Agricultural Experiment Station, Baton Rouge, LA. pp. 148-159.

Drew, T.J. and J.W. Flewelling. 1977. Some recent Japanese theories of yielddensity relationships and their application to Monterey pine plantations. Forest Science 23: 517-534.

Drew, T.J. and J.W. Flewelling. 1979. Stand density management: an alternative approach and its application to Douglas-fir plantations. Forest Science 25: $518-532$.

Farnden, C.F. 1996. Stand density management diagrams for lodgepole pine, white spruce and interior Douglas-fir. Information Report BC-X-360. 
Government of Canada, Department of Natural Resources, Canadian Forest Service, Pacific Forestry Centre, Victoria, BC.

Farnden, C.F. 2002. Recommendations for constructing stand density management diagrams for the province of Alberta. Report prepared for the Ministry of Alberta Sustainable Resource Development, Alberta Land and Forest Division, Forest Management Section, Research Analysis Section. $17 \mathrm{pp}$.

Flewelling, J.W. and T.J. Drew. 1985. A stand density management diagram for lodgepole pine. In: D.M. Baumgarter, R.G. Krebill, J.T. Arnott JT, and G.F. Weetman (Eds.) Lodgepole Pine: the Species and Its Management. Washington State University, Pullman, WA. pp. 239-244.

Flewelling, J.W., K.N. Wiley and T.J. Drew. 1980. Stand density management in western hemlock. Forestry Research Technical Report 042-1417 /80/32. Weyerhauser Corporation, Western Forestry Research Center, Centralia, WA.

FORDA (Forestry Research and Development Agency). 1991. Arcamanik, Cigerendeng and Cikole Forest Research Booklet. Forestry Research and Development Agency, Ministry of Forestry of Indonesia, Jakarta, Indonesia.

Hatiya, K. and T. Fujimori. 1984. Law of density effect and stand density control diagram. Forestry Agency, Japan International Cooperation Agency, Tokyo, Japan.

Heriansyah, I., S. Bustomi, and Y. Kanazawa. 2006. Self-thinning, size variation and long-term change in increment of merkus pine in a spacing trial. In: Arifin (Ed.) The Future Challenges of Indonesia: Strategies to Build and Enhance the Competitive Advantages. Hiroshima Univ. Japan.

Hidayat, J. and C.P Hansen. 2002. Pinus merkusii Jungh. Et de Vriese. Seed Leaflet. Danida Forest Seed Centre, Hoersholm, Denmark.

Jack, S.B. and J.N. Long. 1996. Linkage between silviculture and ecology: an analysis of density management diagrams. Forest Ecology and Management 86: $205-220$.

Jones, M. and J.L. Harper. 1987. The influence of neighbors on the growth of tree. II. The fate of buds on long and short shoots in Betula pendula. Proceedings of the Royal Society London B 232:19-33

Kim, D.K., J.W. Kim, S.K. Park, M.Y. Oh, and J.H. Yoo. 1987. Growth analysis of natural pure young stand of red pine in Korea and study on the determination of reasonable density. Research Reports of the Forestry 
Institute no. 34. Government of Korea, Seoul. pp. 32-40. [In Korean with English abstract].

Kira, T. (Ed.). 1957. Stand density, competition, and production. Osaka Registration Forestry Office 8:13-24, 9:9-18, 12:34-35.

Kira, T., H. Ogawa, and Y. Sakazaki. 1953. Intraspecific competition among higher plants. I. Competition-density-yield interrelationship in regularly dispersed population. Journal of the Institute of Polytechnics. Osaka City University Series D4:1-16.

Kira, T., H. Ogawa, and K. Hozumi. 1954. Intraspecific competition among higher plants. II. Further discussion on Mitscherlich 's law. Journal of the Institute of Polytechnics. Osaka City University Series D5:1-7.

Kira, T., H. Ogawa, K. Hozumi, and K. Yoda. 1956. Intraspecific competition among higher plants. V. Supplementary notes on the C-D effect. Journal of the Institute of Polytechnics. Osaka City University Series D7:1-14.

Kumar, B.M., J.N. Long, and P. Kumar. 1995. A density management diagram for teak plantations of Kerala in peninsular India. Forest Ecology and Management 74:125-131.

Long, J.N. 1985. A practical approach to density management. The Forestry Chronicle 23: 23-26.

Long, J.N., J.B. McCarter, and S.B. Jack. 1988. A modified density management diagram for coastal Douglas-fir. Western Journal of Applied Forestry 3: 88-89.

McCarter, J.B. and J.N. Long. 1986. A lodgepole pine density management diagram. Western Journal of Applied Forestry 1: 6-11.

Newton, P.F. 1997. Stand density management diagrams: review of their development and utility in stand-level management planning. Forest Ecology and Management 98: 251-265.

Newton, P.F. 1998. Regional-specific algorithmic stand density management diagram for black spruce. Northern Journal of Applied Forestry 15: 94-97.

Newton, P.F. and G.F. Weetman. 1994. Stand density management diagram for managed black spruce stands. The Forestry Chronicle 70: 65-74.

Oliver, C.D. and B.C. Larson. 1990. Forest stand dynamics. McGraw-Hill, New York, NY. 467 pp.

Perum Perhutani (State-Owned Enterprise of Java). 2001. Statistic of 1996-2000. Jakarta, Indonesia.

Reineke, L.H. 1933. Perfecting a stand density index for even-aged forest. Journal of Agricultural Research 46: 627-638. 
Shinozaki, K. 1959. Self-thinning. In: Numata M (Ed.) Forest Ecology (1) Kokon-Shoin, Inc. Tokyo, Japan. pp. 178-180.

Shinozaki, K. and T. Kira. 1956. Intraspecific competition among higher plants. VII. Logistic theory of the C-D effect. Journal of the Institute of Polytechnics. Osaka City University Series D7: 35-72.

Shinozaki, K. and T. Kira. 1961. Intraspecific competition among higher plants. $\mathrm{X}$. The C-D rule, its theory and practical uses. Journal of Biology. Osaka City University Series 12: 69-78.

Tadaki, Y. 1963. The pre-estimating of stem yield based on the competition density effect. Bulletin no. 154. Government Forest Experiment Station, Tokyo, Japan [In Japanese with English summary].

Yoda, K., T. Kira, H. Ogawa, and K. Hozumi. 1963. Self-thinning in overcrowded pure stands under cultivated and natural conditions. Journal of Biology. Osaka City University Series 14: 107-129. 
